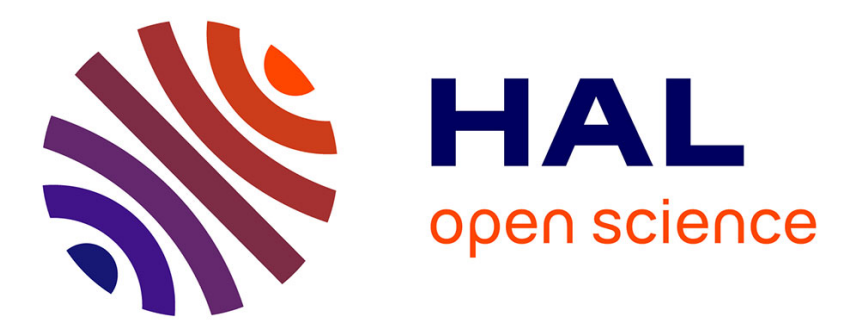

\title{
Genetic homogenisation of birth weight in rabbits : Indirect selection response for uterine horn characteristics
}

Gerard Bolet, Herve H. Garreau, Thierry Joly, Michèle Theau Clément, Jacky Falières, J. Hurtaud, Loys L. Bodin, . Station d'Amélioration Génétique Des Animaux

\section{To cite this version:}

Gerard Bolet, Herve H. Garreau, Thierry Joly, Michèle Theau Clément, Jacky Falières, et al.. Genetic homogenisation of birth weight in rabbits: Indirect selection response for uterine horn characteristics. Livestock Science, 2007, 111, pp.28-32. hal-02653561

\section{HAL Id: hal-02653561 https://hal.inrae.fr/hal-02653561}

Submitted on 29 May 2020

HAL is a multi-disciplinary open access archive for the deposit and dissemination of scientific research documents, whether they are published or not. The documents may come from teaching and research institutions in France or abroad, or from public or private research centers.
L'archive ouverte pluridisciplinaire HAL, est destinée au dépôt et à la diffusion de documents scientifiques de niveau recherche, publiés ou non, émanant des établissements d'enseignement et de recherche français ou étrangers, des laboratoires publics ou privés. 


\title{
Genetic homogenisation of birth weight in rabbits: Indirect selection response for uterine horn characteristics
}

\author{
G. Bolet $^{\mathrm{a}, *}$, H. Garreau ${ }^{\mathrm{a}}$, T. Joly $^{\mathrm{b}}$, M. Theau-Clement ${ }^{\mathrm{a}}$, \\ J. Falieres $^{\text {a }}$, J. Hurtaud ${ }^{\text {c }}$, L. Bodin ${ }^{\text {a }}$ \\ a INRA, SAGA, BP 52627, F31326 Castanet-Tolosan, France \\ b ISARA, 31 place Bellecour, F69002, Lyon, France \\ c GRIMAUD FRERES Sélection, La Corbière F49450 Roussay, France
}

Received 9 June 2006; received in revised form 14 November 2006; accepted 15 November 2006

\begin{abstract}
A divergent selection experiment on within-litter homogeneity of birth weight in rabbits was carried out at the INRA experimental farm at Auzeville. The two lines were created by selecting breeding does and bucks from the female strain AGP22 bred at the Grimaud Frères Sélection Company. This involved a new model incorporating a genotypic value for the mean of individual birth weight and a genotypic value for the environmental variance. This new "trait" was modelled in the usual infinitesimal framework, giving estimated breeding values for environmental variability. There was a favourable selection response with a significant difference in within-litter standard deviation of birth weight between the lines selected for increasing (HOM) or decreasing (HET) homogeneity. At the end of the third generation, 31 females from the HOM line and 33 from the HET line were sacrificed to collect the uterine horns and measure their initial length $(L 1)$ and their length after elongation with a weight of $50 \mathrm{~g}$ $(L 2)$ and then $70 \mathrm{~g}(L 3)$. The length in the homogeneous line was significantly greater, whatever the weight $(L 1:+1.3 \mathrm{~cm}, P=0.02$; $L 2:+2.8 \mathrm{~cm} P<0.001 ; L 3:+4.2 \mathrm{~cm}, P<0.001)$. The absolute and the relative elongations were significantly higher in the HOM line. There was no significant effect of the line on the number of ova shed, the weight of the ovary, or the weight of the uterine horns. It is concluded that the divergence between lines for the within-litter homogeneity of birth weight is at least partly due to the characteristics of the genital tract, i.e. the length and capacity for elongation of the uterine horn.
\end{abstract}

(C) 2006 Elsevier B.V. All rights reserved.

Keywords: Rabbit; Homogenisation; Selection; Litter weight; Uterus

\section{Introduction}

Rabbit birth weight presents a great variability within each litter (Bolet et al., 1996). Reducing this heterogeneity may be useful for the rabbit industry, since it induces a high mortality, as a result of the loss of the weakest

\footnotetext{
* Corresponding author. Tel.: +33 5612851 68; fax:+33 561285353

E-mail address: Gerard.bolet@toulouse.inra.fr (G. Bolet).
}

rabbits. In heterogeneous litters the weakest animals are also more sensitive to disease and can contaminate the whole litter (Poignier et al., 2000). Grading birth weight and fostering methods have been shown to improve preweaning survival (Perrier, 2003) but these methods are stressful and can contribute to the spread of disease.

On the contrary, selection for reducing heterogeneity would be a very convenient method. In quantitative genetics, heteroscedastic models have been developed with the hypothesis that in addition to the environmental 
factors, genetic factors can also modify the environmental variability (San Cristobal-Gaudy et al., 1998, 2001; Sorensen and Waagpetersen, 2003). Several authors have estimated genetic parameters of the variability of a character in animal production, either for litter size in sheep (San Cristobal-Gaudy et al., 2001), or for pig birth weight (Damgaard et al., 2003; Huby et al., 2003). These new methods lead to the estimation of the additive genetic part of the environmental variance. It is generally low, but it would allow a genetic response to this selection named "canalising" (Bodin et al., 2002; Hill, 2002). In order to study that possibility of selection and to measure its effectiveness through the genetic progress that could be obtained, a divergent selection program for the within-litter homogeneity of rabbit birth weight was initiated.

\section{Material and methods}

\subsection{Selection of divergent lines for the within-litter homogeneity of rabbit birth weight}

The objective of selection was to decrease the environmental variability of birth weight in one line (HOM) and increase it in the other (HET). It is based on the original hypothesis that, in addition to the classical genetic effects acting on the mean production level, other genetic factors may act on the residual variance and allow modifying by selection for the environmental variability (San Cristobal-Gaudy et al., 1998; Sorensen and Waagpetersen, 2003). This environmental variability was reached in two steps: first a mixed model was fitted on individual birth weight considered as a trait of the dam; then log squared residuals were computed and considered as a measure of environmental variability. This new "trait" was modelled in the usual infinitesimal framework, giving estimated breeding values for environmental variability.

The two divergent lines were created for low (homogeneous line or HOM) and high (heterogeneous line or HET) environmental variability of birth weight from 193 females and 108 males alive in the AGP22 strain (Grimaud Frères Sélection company) at the beginning of the experiment. Fifteen females and 4 males with lowest genetic values for the within-litter homogeneity of birth were chosen to constitute the G0 generation as the base of the heterogenous line (HET). In the same way, 14 females and 5 males with the highest genetic values were chosen as the base for the homogenous line (HOM). The females were housed in an INRA experimental farm of the Station d'Amélioration Génétique des Animaux (SAGA) at Auzeville. The selected males were kept in the nucleus and fresh semen was sent to Auzeville in order to inseminate the does. Three series of artificial inseminations (every 6 weeks) provided 50 litters (26 and 24, respectively, for the HOM and HET lines). A new genetic evaluation was made after the third kindling and 68 daughters from the HOM line and 96 from the HET line were kept to constitute the G1 generation. Those females were inseminated 3 times with sires of the nucleus (9 HOM and 7 HET sires) to provide the phenotypes of that generation. The same scheme was applied to the following generations.

\subsection{Estimation of genetic parameters}

Estimation of genetic parameters and calculation of breeding values were based on a mixed heteroscedastic model. This model, associated with a single phenotypic value, assumes that the mean production level depends on classical fixed and random effects and that the residual variance can be decomposed into a part under genetic control and the usual unexplained variability (San Cristobal-Gaudy et al., 1998).

\subsection{Characteristics of the genital tract}

After the weaning of their fourth litter in the G3 generation, 31 females from the HOM line and 33 females from the HET line were sacrificed. They had been inseminated $72 \mathrm{~h}$ before, after a superovulation treatment to get embryos to be frozen for the national French cryobank.

After slaughtering, the genital tract was collected. Each uterine horn was separated from the corresponding oviduct. The connective tissue was removed to allow its stretching. Each uterine horn was first perfused to collect the embryos and weighed. Then, it was hung on a support and measured immediately (length $=L 1)$. A $5 \mathrm{~g}$ weight was added for the measurement of $L 1$. Then a $50 \mathrm{~g}$ weight was added and the horns were measured again $1 \mathrm{~min}$ later (length=L2). Finally, a $70 \mathrm{~g}$ weight was added to measure length $L 3 \quad 1$ min later (length $=L 3$ ). Some uterine horns broke during the elongation test, so that the number of data is smaller for $L 3$ then for $L 2$. For $L 1$, some data were missing.

\subsection{Statistical analysis}

\section{We analysed:}

- the length of each uterine horn ( $L 1, L 2$ and $L 3)$;

- its absolute elongation: $\Delta 1=L 2-L 1, \Delta 2=L 3-L 2$, $\Delta T=L 3-L 1$;

- its relative elongation: $\Delta \% 1=(L 2-L 1) / L 1, \Delta \% 2=$ $(L 3-L 2) / L 2, \Delta \% T=(L 3-L 1) / L 1$; 
Table 1

Results of the analysis of variance: number of data $(n)$, overall mean, residual standard error (RSE), $P$ values for independent variables ${ }^{1}$

\begin{tabular}{|c|c|c|c|c|c|c|c|c|c|}
\hline & \multirow[t]{2}{*}{$n$} & \multirow[t]{2}{*}{ Mean } & \multirow[t]{2}{*}{ RSE } & \multirow{2}{*}{$\begin{array}{l}R^{2} \\
(\%)\end{array}$} & \multicolumn{5}{|l|}{$P$ value } \\
\hline & & & & & Line & Side & NV & Group & Treatment \\
\hline \multicolumn{10}{|l|}{ Length of the uterine horn } \\
\hline Initial (with a weight of $5 \mathrm{~g}): L 1(\mathrm{~cm})$ & 93 & 13.8 & 2.6 & 19 & 0.02 & 0.16 & 0.01 & 0.36 & 0.74 \\
\hline With a weight of $50 \mathrm{~g}: L 2(\mathrm{~cm})$ & 97 & 20.2 & 3.9 & 24 & $<0.001$ & 0.11 & 0.01 & 0.57 & 0.93 \\
\hline With a weight of $70 \mathrm{~g}: L 3(\mathrm{~cm})$ & 68 & 22.3 & 4.1 & 35 & $<0.001$ & 0.07 & 0.03 & 0.78 & 0.24 \\
\hline \multicolumn{10}{|l|}{ Absolute elongation of the uterine horn } \\
\hline$\Delta 1(\mathrm{~cm})=L 2-L 1$ & 92 & 6.5 & 2.0 & 22 & $<0.001$ & 0.08 & 0.21 & 0.48 & 0.52 \\
\hline$\Delta 2(\mathrm{~cm})=L 3-L 2$ & 68 & 2.5 & 1.2 & 21 & 0.02 & 0.69 & 0.09 & 0.41 & 0.22 \\
\hline$\Delta T(\mathrm{~cm})=L 3-L 1$ & 63 & 8.6 & 2.4 & 30 & $<0.001$ & 0.15 & 0.26 & 0.73 & 0.57 \\
\hline \multicolumn{10}{|l|}{ Relative elongation of the uterine horn } \\
\hline$\Delta \% 1(\%)=(L 2-L 1) / L 1$ & 92 & 47.9 & 13.2 & 13 & 0.01 & 0.20 & 0.91 & 0.18 & 0.27 \\
\hline$\Delta \% 2(\%)=(L 3-L 2) / L 2$ & 63 & 12.6 & 6.40 & 14 & 0.18 & 0.79 & 0.25 & 0.33 & 0.09 \\
\hline$\Delta \% T(\%)=(L 3-L 1) / L 1$ & 63 & 64.9 & 17.6 & 14 & 0.01 & 0.66 & 0.66 & 0.39 & 0.42 \\
\hline Weight of the uterine horn $(\mathrm{g})$ & 98 & 9.74 & 2.11 & 4 & 0.32 & 0.54 & 0.24 & 0.84 & 0.71 \\
\hline Weight of the ovary (g) & 96 & 0.51 & 0.14 & 6 & 0.43 & 0.64 & 0.17 & 0.28 & 0.66 \\
\hline Number of corpora lutea & 98 & 14.5 & 6.3 & 7 & 0.08 & 0.66 & 0.81 & 0.90 & 0.07 \\
\hline
\end{tabular}

${ }^{1}$ Line: HOM vs.HET (divergent lines selected for homogeneity or heterogeneity of the environmental variance of birth weight, respectively). Side: left $v s$. right uterine horns.

$\mathrm{NV}$ : number of young born in the preceding litter $(0,1-8,9-15)$.

Group: D1 vs D2 inseminations.

Treatment: Superovulation treatment at one or seven days after weaning the previous litter.

- its weight; and the weight of each ovary and the number of corpora lutea after superovulation.

We used a fixed effects model of analysis of variance including the following effects:

- the line: HOM vs HET

- the number of young born in the preceding litter: 0 (no litter), or 1 to 8 , or 9 to 15

- the side of the uterine horn (left or right, the data of each uterine horn are analysed individually)

- the group: inseminations were made on two successive days (D1 and D2)

- the treatment: The superovulation treatment began one day or one week after the weaning of the previous litter.

In a preliminary analysis of the data, no significant interactions between the main effects were detected, so interactions were removed from the statistical model.

\section{Results}

\subsection{Effect of the line}

There was a significant effect of the line on most of the characteristics of the uterine horn (Table 1 and
Fig. 1). Its length was significantly higher in the homogeneous line, whatever the moment $(L 1:+1.3 \mathrm{~cm}$, $P=0.02 ; L 2:+2.8 \mathrm{~cm} P<0.001 ; L 3:+4.2 \mathrm{~cm}, P<0.001)$.

The absolute elongation was significantly higher in the HOM line between $T 1$ and $T 2(+1.6 \mathrm{~cm}, P<0.001)$, between $T 1$ and $T 2(+0.8 \mathrm{~cm}, P=0.02)$ and globally between $T 1$ and $T 3(+2.5 \mathrm{~cm}, P<0.001)$.

The relative elongation was significantly higher in the HOM line between $T 1$ and $T 2(+7.7$ points, $P<0.01)$ and globally between $T 1$ and $T 3(+12$ points, $P=0.01$ ) but not between $T 2$ and $T 3$.

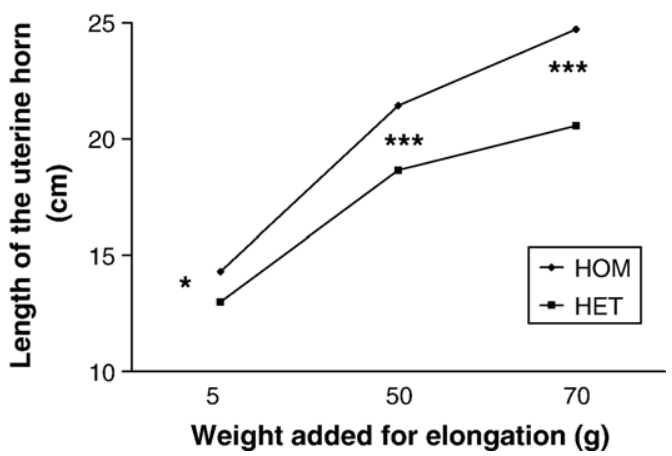

Fig. 1. Effect of the line (HOM: homogenous vs HET: heterogenous) on the initial length $(L 1,5 \mathrm{~g}$ added $)$ and elongation $(L 2,50 \mathrm{~g}$ added and $L 3,70 \mathrm{~g}$ added) of the uterine horn. ${ }^{*} P<0.05 * * * P<0.001$. 


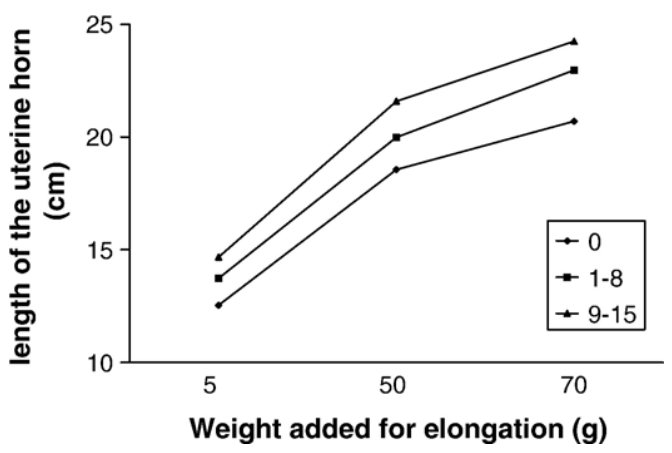

Fig. 2. Effect of the number of young in the preceding litter $(0$, from 1 to 8 or from 9 to 15$)$ on the initial length ( $L 1,5 \mathrm{~g}$ added) and elongation ( $L 2,50 \mathrm{~g}$ added and $L 3,70 \mathrm{~g}$ added) of the uterine horn.

\subsection{Effect of the previous litter}

This experiment took place at the end of the 3rd generation, at the time of weaning of the 4th litter, but some of these females had not been lactating at this time. There was a significant effect of the previous litter on the length of the uterine horn. It was significantly longer when a litter was born in the preceding 40 days, and when this litter had more than 8 young, whatever the stage of elongation ( $L 1, L 2$ or $L 3)$, but there was no significant effect on the absolute or relative elongation (Table 1 and Fig. 2).

\subsection{Other effects}

The other effects used in the statistical model were not significant, whatever the trait. There were no differences between the right and the left uterine horn. Neither the time elapsed between weaning and the time of the superovulation treatment nor the group affected the measured traits.

The number of ova shed, the weight of the ovary and the weight of the uterine horn were also measured but none of these traits was affected by the line or other effects of the model (Table 1).

\section{Discussion}

In spite of the significant response to selection, neither the average weight of young nor the litter size at birth differ between the HOM and HET lines (Garreau et al., 2004 and unpublished data). It could have happened because of the negative correlation between litter size and average young weight, or because the presence of more runts in large litters increases the variance of birth weight. This result can be explained by the statistical method used to select the divergent lines, which avoids bias due to correlations between mean and variance.

On the other hand, the divergence between lines for the characteristics of the uterine horns can be considered as an important component of the efficiency of selection.

It has already been shown that there is a great heterogeneity of foetus weight (Bolet et al., 1996), which may be influenced by its location in the uterine horn (Lebas, 1982). In this experiment, the litter weight at birth is considered as a trait of the rabbit doe. Since the divergent selection for the heterogeneity of young weight at birth within litter has been efficient (Garreau et al., 2004), we can suppose that it is due to a response on some anatomical or physiological characteristics of the genital tract. The results of this experiment confirm this hypothesis.

In pigs, Chen and Dziuk (1993) examined the influence of the initial length of uterus per embryo on prenatal survival and development. Their conclusion was that there was some influence of available space per foetus on prenatal survival when this space was reduced (less than $25 \mathrm{~cm}$ per corpus luteum), but no significant effect of space restriction on either foetal length or weight.

In the rabbit, Bolet et al. (1996) compared the weight of young rabbits from does either unilaterally ovariectomised or normal. There was a significant effect of litter size on young weight, but a very limited effect of available uterine space on weight. They concluded that the difference of weight according to litter size is essentially due to nutritional competition. Argente et al. (2003, 2004) compared the characteristics and the irrigation of the uterine horns in two lines differing in their uterine capacity. Their results suggest that each embryo requires a minimum space in the uterus to attach, survive, and grow. They found that the available space in the uterus seems to affect especially the development of maternal placenta, and to a lesser extent the development of the foetus and its foetal placenta. Thus, it seems that the initial length and available uterine space has a rather small effect on foetal growth and foetus weight.

Our results do not include data on foetus weight, but only on uterus characteristics in these two lines. The initial length $(L 1)$ differs less significantly $(P=0.02)$ than the length after elongation ( $L 2$ and $L 3, P<0.001$ ) between the two lines. The capacity for elongation of the uterus seems to be a major component of its efficiency.

\section{Conclusion}

This experiment shows a significant difference between the two divergent lines for the characteristics 
of the uterine horns, i.e. their length and capacity of elongation, in favour of the line selected for a better homogeneity of young birth weight.

Under the influence of at least oestrogen and progesterone, the myometrium undergoes hyperplasia and hypertrophy during pregnancy (Gilloteaux and Szczepanski, 2000). It would be interesting to compare the characteristics of the uterine smooth muscle between the two lines. However, the method we used is rather rudimentary and could be improved by measuring the compliance, i.e. the inverse of stiffness, of the uterine horns.

\section{Acknowledgment}

We wish to thank Mrs Wendy Brand-Williams for the English revision of the paper.

\section{References}

Argente, M.J., Santacreu, M.A., Climent, A., Blasco, A., 2003. Relationships between uterine and fetal traits in rabbits selected on uterine capacity. J. Anim. Sci. 81, 1265-1273.

Argente, M.J., Santacreu, M.A., Climent, A., Blasco, A., 2004. Effects of intrauterine crowding on uterine available space per fetus in rabbits. 8th World Rabbit Congress, Puebla City - Mexico, September 7-10, 2004, pp. 207-212.

Bodin, L., Robert-Granié, C., Larzul, C., Allain, D., Bolet, G., Elsen, J.M., Garreau, H., Rochambeau de, H., SanCristobal, M., 2002. Twelve remarks on canalization in livestock production. In: Elsen, J.M., Ducrocq, V. (Eds.), Proceedings of the 7th World Congress on Genetics Applied to Livestock Production, 19-23 August 2002, vol. 32. Montpellier, com. 19-03 (CD-Rom).

Bolet, G., Esparbié, J., Falières, J., 1996. Relations entre le nombre de fœtus par corne utérine, la taille de portée à la naissance et la croissance pondérale des lapereaux. Ann. Zootech. 45, 185-200.
Chen, Z.Y., Dziuk, P.J., 1993. Influence of initial length of uterus per embryo and gestation stage on prenatal survival, development, and sex ratio in the pig. J. Anim. Sci. 71, 1895-1901.

Damgaard, L.H., Rydhmer, L., Lovendahl, P., Grandinson, K., 2003. Genetic parameters for within-litter variation in piglet birth weight and change in within-litter variation during suckling. J. Anim. Sci. 81, 604-610.

Garreau, H., San Cristobal, M., Hurtaud, J., Bodin, L., Ros, M., Robert-Granié, C., Saleil, G., Bolet, G., 2004. Can we select on within litter homogeneity in rabbit birth weight? A divergent election experiment. 8th World Rabbit Congress, Puebla City Mexico September 7-10, 2004, pp. 63-68.

Gilloteaux, J., Szczepanski, M., 2000. The fibre dimensions of uterine smooth muscle of the rabbit following treatment by female sex steroids. Tissue Cell 32, 243-248.

Hill, W.G., 2002. Direct effects of selection on phenotypic variability of quantitative traits. In: Elsen, J.M., Ducrocq, V. (Eds.), Proceedings of the 7th World Congress on Genetics Applied to Livestock Production, 19-23 August 2002, vol. 32. Montpellier, com. 19-02 (CD-Rom).

Huby, M., Gogué, J., Maignel, L., Bidanel, J.P., 2003. Corrélations génétiques entre les caractéristiques numériques et pondérales de la portée, la variabilité du poids des porcelets et leur survie entre la naissance et le sevrage. J. Rech. Porcine 35, 293-300.

Lebas, F., 1982. Influence de la position in utero sur le développement corporel des lapereaux. 3èmes Journées de la recherche cunicole, 8-12 december 1982, Paris, com. ${ }^{\circ} 16$. ITAVI, Paris.

Perrier, G., 2003. Influence de l'homogénéité de la portée sur la croissance et la viabilité des lapereaux de faible poids à la naissance. 10èmes Journées de la recherche cunicole, 19-20 november 2003, Paris. ITAVI, Paris, pp. 119-122.

Poignier, J., Szendrö, Zs., Levai, A., Radnai, I., Biro-Nemeth, E., 2000. Effect of birth weight and litter size on growth and mortality in rabbit. World Rabbit Sci. 8, 103-109.

San Cristobal-Gaudy, M., Elsen, J.M., Bodin, L., Chevalet, C., 1998. Prediction of the response to a selection for canalisation of a continuous trait in animal breeding. Genet. Sel. Evol. 30, 423-451.

San Cristobal-Gaudy, M., Bodin, L., Elsen, J.M., Chevalet, C., 2001. Genetic components of litter size variability in sheep. Genet. Sel. Evol. 33, 249-271. 